\title{
IMPROVING STUDENTS' CRITICAL THINKING DURING COVID-19 THROUGH ONLINE LEARNING
}

\author{
Ambuy Sabur', Dadang Saepuloh ${ }^{2 *}$, Reva Triana ${ }^{3}$ \\ ${ }^{1,2,3}$ Program Studi Pendidikan Ekonomi, Universitas Islam Syekh-Yusuf Tangerang \\ 1email: ambuy@unis.ac.id \\ 2email: dsaepuloh@unis.ac.id \\ 3email: revatritri@gmail.com \\ *Correspondence Author
}

\begin{abstract}
The application of Problem Based Learning model by online learning during the Covid19 period is one way to improve students' thinking abilities. This research aims to obtain empirical data about the comparison of student's critical thinking skills levels by using the online based Problem Based Learning (PBL) model using the Zoom application and Whatsapp Grup in class X IPS SMAN 5 Tangerang Regency. The method of this research used quantitative that is quasi-experimental design. This research's samples were class XIPS as an experimetal class or class A and class X IPS 2 as a control class or class B. The researcher analyzed the data in descriptive statistic by using SPSS 25 version. The results showed that applying the Problem Based Learning model has apositive impact on improving student's critical thinking skills.
\end{abstract}

Keywords: Problem Based Learning (PBL); Critical Thinking; Covid-19; Daring

Abstrak: Penerapan model pembelajaran Problem Based Learning melalui daring pada masa covid-19 merupakan salah satu cara untuk meningkatkan kemampuan berpikir siswa. Tujuan penelitian ini untuk memperoleh data empiris tentang perbandingan tingkat berpikir kritis siswa dengan menggunakan model pembelajaran Problem Based Learning (PBL) berbasis onine dengan menggunakan aplikasi Zoom dan Whatsaap Grup pada siswa kelas X IPS SMAN 5 Kabupaten Tangerang. Metode penelitian ini menggunakan kuantitatif yaitu quasi eksperimen desain. Sampel dalam penelitian ini adalah kelas X IPS 1 sebagai kelas eksperimen atau kelas A dan kelas X IPS 2 sebagai kelas control atau kelas B. Pengumpulan data dilakukan dengan tes, dokumentasi dan observasi. Peneliti menganalisis data secara statistic deskriptif dengan menggunkan SPSS 25 versi. Hasil penelitian menunjukan bahwa penerapan model Problem Based Learning berdampak positif dalam meningkatkan kemampuan berpikir kritis siswa.

Kata kunci: Model Pembelajaran Berbasis Masalah; BerpikirKritis; Covid-19; Daring

\section{INTRODUCTION}

After the pandemic hit Indonesia caused by the Corona virus, the government has done many ways to break the chain of its spread(Firman \& Rahman, 2020). The COVID-19 pandemic attack has changed all habits in learning education, carried out directly or face-to-face with all its strategies, now it cannot run optimally. (Satrio et al. 2020). Changes to the school learning system are implemented online or online. (Kurniawansyah \& Siswanto, 2020). The learning process can be accessed using the internet network (Sadikin \& Hamidah, 2020). The online learning methods used include webinars, use of the Zoom application, Whatsaap, Web, Youtube videos, etc (Marbun, 2020).

The ability to think criticallyis essential so that individuals in the future do not immediately believe in receiving information, are not easily influenced, and will always correct the truth of the information they get. (Anwar et al. 2017). 
Likewise, with the learning process, students must master critical thinking to change their thinking patterns towards articals to dig up the information they get. (Dewi, 2020).Yuliati, (2013) said that critical thinkingcould be taught and trained so that studentscan analyze information in their mindsto determine or make intelligent decisions.

US-based Partnership for $21^{\text {st }}$ Century skills Zubaidah, (2018) The skills individuals need in the 21st century include Critical Thinking Skills, Creative Thinking Skills, Communication Skills and Collaboration Skills as essential competencies that must be mastered by individuals in the $21 \mathrm{st}$ century. This competency, known as 4C through UNESCO 4C consists of collaboration, critical thinking, creativity and communication which is the basis for developing student abilities. Several countries have adopted this concept to make changes and reforms to the education and learning system (Sulisworo at al. 2019).
Based on data from Partnersihip for 21st Century skills APEC Ed Net-Xi'an Symposium Xi'an China Kay, (2008) The skills that individuals in the 21st century must master include: (1) critical thinking (78\%); (2) information technology (77\%); (3) health and fitness (76\%); (4) collaboration (74\%); (5) innovation (74\%); (6) personal financial responsibility $(72 \%)$. The results of the 2018 PISA (Program for International Student Assessment) report released by the Organization for Economic Cooperation and Development (OCED) the results of students' reading, math, and science or science abilities decreased. So that Indonesia's position is ranked 72 out of 77 countries. As a comparison, Indonesia's PISA score for the 2015-2018 period, the reading ability score fell from 397 points to 371 points, while the math ability score from 386 points to 379 and the science ability score from 403 to 396 points (Summaries, 2018). If seen from some of the data reports above, it can be concluded that Indonesian student's critical thinking skills are still low.

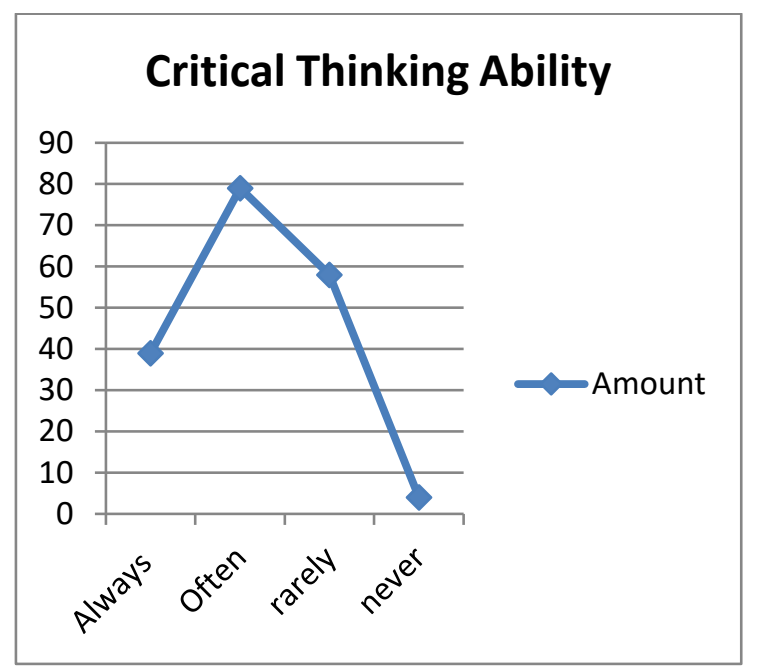

Figure 1. Pre-Research Data

Based on the results of pre-research data conducted at school byanalyzing through the critical thinking indicators of Ennis's theory, namely being able to ask questions, answer questions, analyze arguments, make conclusions, and evaluate and assessing skills. The observations used as a questionnaire to be filled in by 26 students as the sample showed that $22 \%$ always answered, $44 \%$ often answered , 32\% 
rarely answered, $2 \%$ answered never. So it can be concluded that the critical thinking criteria of students of SMAN 5 Tangerang Regency are in the medium category. Only a few schools implement the learning that leads to the critical thinking skills (Santrok, 2011).

This is confirmed by the opinion Anindhyta at al. (2019) which says that in reality in the field, the learning process that takes place in the class emphasizes the cognitive aspects only, so that the critical thinking process of students in receiving learning is less attention. Therefore, many students do not understand the concepts taught by the teacher. Currently, students' critical thinking skills cannot be developed optimally. It is still seen that students have not actively participated in the learning process (Santoso, 2016).

Teachers still dominate conventional learning models (Saepuloh \& Suryani, 2020). Teacher-centered learning causes students' critical thinking skills to below, so it is very contrary to the 2013 curriculum, where students should play an active role in learning activities. (Candrarini at al. 2018).

They are Learning models, methods and strategies to improve vibrant, innovative, creative, practical learning atmosphere and make students happy so that learning can be maximized (Saepuloh \& Rodiah, 2020). Teachers should be able to create an adapted learning model based on the applied curriculum and the conditions in class so that the learning process can foster learning situations that are varied, challenging, fun, and meaningful (Diani, 2016).

The Selection of the right learning model is a critical success factor in teaching and learning activities (Masini at al. 2019). Therefore, teachers play anessential role in the learning process in class and school (Surur \& Oktavia, 2019). Inappropriate learning models cause student's Students' low critical thinking skills. The learning model must be able to provide ample space for students to build knowledge (Manalu \& Siregar, 2019). Developing critical thinking skills is a real process in learning activities and provides meaningful learning, by thinking critically will help study problems naturally so that students can make the right decisions (Tosuncuoglu, 2018).

Critical thinking must be developed by each student the can skills students understand the concept,they are sensitive to the problems that occur to understand the situation and can solve the problems they face. (Susanto, 2013). To develop students' canning skills, the teacher must be able to design a learning model that emphasizes the thinking process of students so that they can analyze and be able to solve problems; besides that, the involvement of students who play an active role must be considered in the selection of learning models (Anindhyta et al., 2019).

An active learning process that involves students can increase critical thinking skills, therefore critical thinking is one of the skills that students must master (Hidayati, 2016). Thinking activities in the learning process cannot be separated from critical and creative thinking activities. Critical thinking is an activity to train and assess something carefully, such as assessing ideas, the purpose of critical thinking to consider based decision making (Noordyana, 2016).

Efforts that can be taken to overcome the above problems are to improve the learning model, in learning activities the teacher must apply the appropriate learning model and in learning objectives to be achieved. (Muslim at al. 2015). Teachers can build learning that can train students' critical thinking skills, choose the right learning model and create learning activities that make students develop all their potential so 
that they can improve their critical thinking skills. (Nuryanti at al. 2018).

The development of a studentcentered learning model will be able to build critical thinking and be able to solve a problem. One learning model that can train students' critical thinking skills is problembased learning (Simanjuntak \& Sudibjo, 2019). The PBL model is a learning model that focuses on analyzing and thinking critically of students about the problems they face. This model is based on real-life problems so that students can dig deeper for information or find a solution to solve a problem (Widayanti, 2020). The Problem Based Learning model is student-centered learning in solving a problem, the teacher is problems that exist in real life. Therefore, the application of this learning model can provide direct experience experienced by students and will be able to solve problems that will occur in everyday life (Asriningtyas at al. 2018).

According to Apriyani at al. (2017) learning involves students in solving problems, one of the high-ranking thinking skills is critical thinking skills that can be trained in problem-solving in the learning process. This is in line with the opinion Setyorini , (2011) said that the PBL learning process could improve students' critical thinking skills. The teacher will give problems, and then in groups they discuss the problems and exchange ideas in collaboration to obtain solutions.

Researchers discuss two variables, namely the Problem Based Learning learning model with online or online based and critical thinking whereas the previous researchers discussed more variables related to students' critical thinking skills. Online learning is a learning technique that utilizes technology in teaching and learning activities (Satrio et al., 2020). In practice, online learning requires a smartphone, tablet or laptop to access information on the internet anywhere and anytime (Gikas \& Grant, 2013). In this study, researchers used an online-based Problem Learning model using the Zoom and Whatsapp Group applications. Implementation of online learning approaches face to face using video conferencing applications including webinars zoom (Yulianto at al. 2020). Webinar zoom is a face-to-face conference application service where teachers and students can interact directly as if they were in person (Kusuma \& Hamidah, 2020). In addition to zoom online learning can also be implemented using the whatsaap group application, which is the most widely used online message exchange service via whatsaap messenger, namely group conversations or group discussions. Its members can share information (Kurniawansyah \& Siswanto, 2020).

Based on the above background, the researcher asked several questions, How is the implementation of online learning using the Problem Based Learning model? What is the level of students' critical thinking skills using the Problem Based Learning learning model? Moreoveris there a significant difference instudent'slevel of critical thinking skills with the application of the Problem Based Learning and Conventional models? The purpose of this study was to obtain empirical data about the comparison of the level of critical thinking of students using the online-based Problem Based Learning (PBL) learning model using the Zoom and Whatsaap Group application in class X IPS SMAN 5 Tangerang.

\section{METHODS}

This study uses quantitative research with the Quasi-Experimental Desigin research method. This study applies the Problem Based Learning learning model in class X IPS 1 as the experimental class and the conventional learning model in class $\mathrm{X}$ IPS 2 as the control class. The purpose of 
this study was to compare the level of critical thinking skills of students with post-test results after the application of the PBL (Problem Baed Learning) learning model for three meetings. The data collection method used a test on therespondent, critical thinking skills which then the average score was taken to determine the comparison of students' critical thinking skills. This study's subjects were class $\mathrm{X}$ IPS at SMAN 5 Tangerang Regency which consisted of 5 classes totaling 179 students. The sample in this study amounted to 50 students. Testing the validity of the indicators of critical thinking, a total of 12 questions that meet the criteria

The validity test is only six questions, after the validity test is carried out the questions reliability test is 0.675 which means the coefficient is high.

Table 1. Deskriptif Statistik

\begin{tabular}{|c|c|c|c|c|c|c|c|}
\hline & & $\mathbf{N}$ & Min & Max & Mean & $\begin{array}{l}\text { Std. } \\
\text { Deviation }\end{array}$ & Variance \\
\hline Class & A & & & & & & \\
\hline $\begin{array}{l}\text { Posstes } \\
\text { Value }\end{array}$ & & 25 & 33 & 94 & 64.4 & 17.744 & 314.833 \\
\hline Class & B & & & & & & \\
\hline $\begin{array}{l}\text { Posstes } \\
\text { Value }\end{array}$ & & 25 & 33 & 72 & 52.72 & 11.943 & 142.627 \\
\hline $\begin{array}{l}\text { Different } \\
\text { Values }\end{array}$ & & 25 & 0 & 55 & 17.92 & 12.172 & 148.16 \\
\hline $\begin{array}{l}\text { Valid } \\
\text { (listwise) }\end{array}$ & $\mathrm{N}$ & 25 & & & & & \\
\hline
\end{tabular}

Data: Processed SPSS 2020

Based on the descriptive table above, it can be seen that the post-test score for class $\mathrm{A}$ is at a mean value of 64.40 , a minimum value of 33 and a maximum value of 94 with a standard deviation of 17.744. Meanwhile, the mean value of posts in class B was 52.72, the minimum value was 33 and the maximum value was 72 with a standard deviation of 11.943 .

\section{RESULTS AND DISCUSSION}

In the critical thinking ability test, researchers spread six essay questions with the following observations: This research analysis stage is through the test phase, first a descriptive description of the test results from the observation subjects. The second is the test of requirements analysis, the third analyzes themean of the variables with the independent $t$ test. Moreover, the formulation or research analysis results are described as follows, the classification of subjects based on variables. This study focuses on 2 variables, namely the Problem Based Learning model and critical thinking and its explanations.

Testing the requirements of the analysis requirements to determine whether the data is normally distributed or not, the researcher uses the Shapiro Wilk formula to test for normality. The normality test using SPSS 25 is as follows 


\begin{tabular}{|c|c|c|c|c|c|c|}
\hline & \multicolumn{3}{|c|}{ Kolmogorov-Smirnov ${ }^{\mathrm{a}}$} & \multicolumn{3}{|c|}{ Shapiro-Wilk } \\
\hline Class & Statistic & $\overline{\mathrm{Df}}$ & Sig. & Statistic & df & Sig. \\
\hline $\begin{array}{l}\text { Class } \\
\text { A }\end{array}$ & 0.102 & 25 & .200 & 0.961 & 25 & .439 \\
\hline $\begin{array}{l}\text { Class } \\
\text { B }\end{array}$ & 0.136 & 25 & .200 & 0.945 & 25 & .197 \\
\hline
\end{tabular}

Data: Processed SPSS 2020

Based on the normality test above, it can be seen that there is a Shapiro Wilktable which shows that the significant value in group $\mathrm{A}$ is $0.439>0.05$, it can be concluded that the data in class $\mathrm{A}$ are typically distributed. While the normality test in class $B$ has a significance value of $0.179>0.05$, so it can be concluded that the data in class $B$ is usually distributed.

Table 3. Homogeneity Testing

\begin{tabular}{lllll}
\hline & $\begin{array}{l}\text { Levene } \\
\text { Statistic }\end{array}$ & df1 & df2 & Sig. \\
\hline Based on Mean & 4.283 & 1 & 48 & .044 \\
Based on Median & 4.18 & 1 & 48 & .046 \\
$\begin{array}{l}\text { Based on Median and } \\
\text { with adjusted df }\end{array}$ & 4.18 & 1 & 44.2 & .047 \\
\end{tabular}

Data: Processed SPSS 2020

Based on the homogeneity test above, a significance value of $0.044>0.05$ is obtained, it can be said that the data from the study population have the same variants.

Tabel 4. Independent $t$ tes

\begin{tabular}{|c|c|c|c|}
\hline & & $\begin{array}{l}\text { Equal Variances } \\
\text { Assumed }\end{array}$ & $\begin{array}{l}\text { Equal Variances } \\
\text { Not Assumed }\end{array}$ \\
\hline \multirow{4}{*}{$\begin{array}{l}\text { Levene'sTes For Equalty } \\
\text { of Variances }\end{array}$} & $F$ & 4.283 & \\
\hline & Sig. & .044 & \\
\hline & $\mathrm{T}$ & 2.730 & 2.730 \\
\hline & df & 48 & 42.042 \\
\hline \multirow[t]{3}{*}{ t-tes For Equalty of Mean } & Sig. (2-tailed) & 0.009 & 0.009 \\
\hline & Mean Difference & 11.68 & 11.68 \\
\hline & $\begin{array}{ll}\text { Std. } & \text { Error } \\
\text { Difference } & \end{array}$ & 4.2777 & 4.2777 \\
\hline \multirow{2}{*}{$\begin{array}{l}95 \% \text { Confidence Interval of } \\
\text { the Difference }\end{array}$} & Lower & 3.0792 & 3.0476 \\
\hline & Upper & 20.2808 & 20.3124 \\
\hline
\end{tabular}

Tabel 4. Independent $t$ tes 
Based on the results of the t-test the comparison between class A and class B can be seen that the count is 2.730 . While $t$ table can be seen from two sides of df, namely 48 at 2.010 because tcount $>$ from ttable $(2.730>$ 2.010) Ho is rejected and $\mathrm{Ha}$ is accepted. This shows a significant difference between the critical thinking skills of students who apply the Problem Based Learning learning model and the critical thinking skills of students who apply conventional models.

\section{Online Learning (Online) Using Problem Based Learning and Conventional Learning Models}

Learning using the Problem Based Learning model which was carried out in the experimental class began with opening lessons to greet and pray, then the teacher explains the provisions when carrying out online learning through the zoom application, the teacher provides an overview and explains the steps for implementing learning by applying the Problem Based Learning model, namely as follows:

stage 1 student orientation to the problem, namely the teacher conveying learning objectives and motivating students to be involved in the problems to be observed and the teacher providing case studies of economic problems in Indonesia,

stage 2 organizes students in the learning process, namely the teacher assigns students to read and understand the problems observed,

stage 3 guides student investigations independently or in groups, namely the teacher encourages students to find and collect appropriate information or data to solve problems, students identify and investigate problems, then students compile the results of investigations to solve problems,

stage 4 develops and presents the work of the teacher explaining the draft for making a handwritten report on paper and each group compiles and makes a teacher report giving students the opportunity to submit the results of the report and present it.

Stage 5 evaluation and reflection, namely the teacher and students reflect and evaluate in online learning using the zoom application. The learning steps described above aim to make students understand the flow of online learning activities. Furthermore, the teacher conveys the learning objectives that will be achieved by students after participating in learning activities at the ongoing meeting. The teacher gives related problems to the material being studied and motivates students to be involved in the problems to be observed. Students understand the problems that occur then the teacher forms groups of 5 students, each group must read and understand the content of the problem, the teacher encourages each student to find the information or data needed to solve the problem, carry out identification and investigation and then compile the results of the investigation to produce a solution, and the next stage the teacher gives a draft report on the results of group discussions and each group makes a report. The teacher allows students to present the discussionresults via videocallwhatsapp group on the specified day and time. The final stage of the teacher reflects and evaluates together after implementing online learning.

Rachmawati \& Rosy, (2020) PBL learning model is a process of learning activities oriented to solving problems that exist in our lives, which aims to train students to solve problems in a logical way and train to develop students' critical thinking skills. The Problem Based Learning model, which encourages students to be active in the teaching learning process, presents real problems (Nainggolan yanti, 2020). (Fakhriyah, (2014) The problems 
presented are real problems that exist in everyday life as a basis for exploring knowledge and concepts through students' critical thinking skills in solving a problem, problem-based learning activities provide opportunities for students to be able to express opinions and exchange ideas and train critical thinking processes to gain new experiences regarding understanding the content of the material (Rezkillah \& Hayanto, 2020).

In the final activity, the teacher concludes the learning material, provides an attendance link that is filled in by students, the teacher closes the lesson by saying greetings. The implementation of online learning in the control class by applying the conventional learning model, the teacher opens lessons by saying greetings and prayers, explaining the provisions of online learning through the zoom application, then convey the learning objectives that will be achieved by students after participating in learning activities at the ongoing meeting, The teacher conveys the main points of the subject that will be discussed, namely the needs and means of satisfying needs, opportunity costs, and economic principles.

The teacher explains the material using power point slides that are displayed on an online zoom screen, students listen and pay attention to the material being explained. Then the teacher allow students the ask questions regarding material that has not been understood, students and teachers are involved in online discussions. Furthermore, the teacher gives several quiz questions directly which will be answered by students todetermine the extent of understanding the material. In the final activity the teacher concludes the learning material, provides an attendance link that will fill in google form the teacher closes the lesson by saying hello.

\section{How the Level of Students' Critical Thinking Ability Using Problem Based Learning and Conventional Learning Models}

The problem-based learning model applied to class X IPS 1 as an experimental class, when the implementation of online learning students become more active and responsive to what the teacher orders, This can be seen that students are more responsive in solving problems given and able to solve problems. The post-test results after the application of the problem-based learning model on the basic concepts of Economics obtained the highest score of 94 and the lowest score of 33. The student's average score was 64.4. This is because students have been able to answer the questions given and correctly and adequately.

The total number of indicators in the experimental class is 11.95. Based on the six indicators of critical thinking, in indicator 1 the student has explained the ideas related to the case study given which is relatively straightforward and precise, indicator 2 students can analyze things related to the answers are quite clear and precise, indicator 3 students can evaluate the results of the answers by explaining clear and precise reasons, indicator 4 students can filter the required information and data appropriately and produce conclusions using their language that is clear and precise, indicator 5 students can produce their thoughts and be able to solve the problems given by making clear and precise solutions, indicator 6 students can organize themselves to answer questions by correcting the results of the answers are clear and precise.

While the level of critical thinking skills in class X IPS 2 as the control class from the post-test results, the highest score was 72 and the lowest score was 33, the average value was 52.72. This is because students answering questions are not 
maximal, at the time of implementation learning. The teacher plays an active role so that students only listen to the explanations silently. The understanding of the control class material is still lacking. This is because the application of conventional learning models makes students passive.

\section{There is a significant difference in critical thinking skills thatapply problem-based learning and conventional learning models}

Post-test data analysis in the experimental class and control class obtained an average value of 64.4 while the average value in the control class was $\mathbf{5 2 . 7 2}$. The data obtained from the t-test obtained from the different values of the experimental class and the control class can be seen from the tcountof 2,730 while the t-table can be seen from two sides of $\mathrm{df}$ which is 48 at 2.010 because tcount>tcount $(2,730>2,010)$ then $\mathrm{Ha}$ is accepted and $\mathrm{Ho}_{0}$ is rejected. So the conclusion is that applying the problembased learning model can improve students' critical thinking skills with the acquisition of post-test results for class A better than class B.

Bashith, (2017) study shows that problem-based learning affects students 'critical thinking skills and learning outcomes, students' critical thinking abilities in the experimental class are higher than the control class. The research results are corroborated by Odabas, (2009) who said that problem-based learning can improve higher-order thinking skills, namely critical thinking. This research is also strengthened by the results of research conducted by Rezkillah \& Hayanto, (2020) which shows that the application of the Problem Based Learning learning model that uses HOTS category questions can have a significant effect on students' critical thinking skills when compared to the application of conventional models.
Based on the results of research that has been carried out by several previous researchers, shows that the application of the problem-based learning model can improve critical thinking skills, the results of research conducted by researchers have the same measured variables, namely Problem Based Learning and critical thinking As for the difference in previous research carried out before the pandemic in the world so that the learning process is carried out optimallycarried out. In the researchers carry out learning during the pandemic caused by COVID-19 so that the learning process is required to be online or online with limited teaching techniques and existing constraints such as an unstable internet network that makes learning implemented not optimally as well as the application of the learning model in groups is more difficult to manage. Rather than directly.

Learning using the zoom application becomes a new container or place for teaching and learning activities, the zoom application is also one solution to carry out online learning at school or lectures. (Fitriyani \& Kamsi, 2020). The results of research conducted by Kurniawansyah \& Siswanto, (2020) during the COVID-19 pandemic, online learning can be useful by using applications that can support the implementation of learning such as zoom,

WhatsApp group and Google Drive. Strengthened by the results of research conducted by Haqien \& Rahman, (2020) online learning using zoom has advantages and disadvantages including the implementation of learning is less effective due to network/internet constraints, besides that zoom also has the advantage of being more practical and efficient because communication between educators and students is more accessible than communication in writing. Based on the explanation described above, the problem-based learning model can improve 
students' critical thinking skills. Besides online-based learning using the zoom application and whatsapp group is also useful during the COVID-19 pandemic, this research has answered the questions raised so this research is said was successful.

\section{CONCLUSIONS}

The critical thinking level ability of students who apply the Problem Based Learning learning model in the experimental class obtained an average score of 64.4, while the lowest score is 33 and the highest score is 94 . While the average value in the control class was 52.72, the lowest value was 33 and the highest value was 72 . So the level of critical thinking ability of class A students is better than class B's ability level. It can be concluded that the application of the Problem Based Learning learning model can improve class $X$ IPS SMAN 5 Tangerang Regency students. The implementation of online learning has been done well, so it needs to be maintained besides that there are still shortcomings, it needs to be repaired and improved again. Teachers are expected to use a more varied learning model according to the curriculum, $\mathrm{K} 13$, which requires students to play an active role during the learning process, such as the Problem Based Learning model which can improve students' critical thinking skills.

\section{ACKNOWLEDGEMENTS}

The researchers would like to thank the school for permiting to carry out research, and FKIP Syekh-Yusuf Islamic University.

\section{REFERENCE}

Anindhyta, C., Budiharti, R., \& Rahardjo Teguh, D. (2019). Penerapan Model Pembelajaran AIR ( Auditory , Intellectually , and Repetition ) untuk Meningkatkan Kemampuan Berpikir kritis. Jurnal Materi Dan Pembelajaran Fisika (JMPF), 9, 133. https://doi.org/https://doi.org/10.2096 1/jmpf.v9i2.38627

Anwar, B., Munzil, \& Hidayat, A. (2017). Pengaruh Collaborative Learning Dengan Teknik Jumping Task Terhadap Keterampilan Berpikir Kritis dan Hasil Belajar. Jurnal Pembelajaran Sains, 1, 15-25. https://doi.org/http://dx.doi.org/10.179 77/um033v1i2p15-25

Apriyani, L., Nurlaelah, I., \& Setiawati, I. (2017). Penerapan Model PBL Untuk Meningkatkan Keterampilan Berpikir Kritis Ditinjau Dari Kemampuan Akademik Siswa Pada Materi Biologi. 9(1), 43.

Asriningtyas, A. N., Kristin, F., \& Indri, A. (2018). Penerapam Model Pembelajaran Problem Based Learning Untuk Meningkatkan Kemampuan Berpikir Kritis dan Hasil Belajar Matematika Siswa Kelas 4 SD. 5(April), 25. https://doi.org/https://doi.org/10.2671 4/jkpm.5.1.2018.23-32

Bashith, A. (2017). The Effect of Problem Based Learning on EFL Students , Critical Thinking Skill and Learning Outcome. 24(2), 93-102.

Candrarini, P. K., Sunarto, \& Nugroho, A. J. (2018). Penerapan Model Pembelajaran Kolaboratif Dengan Strategi Quantum Teaching Untuk Meningkatkan Kemampuan Berpikir Siswa Pada Mata Pelajaran Marketing Kelas X-6 Kompetensi Keahlian Bisnis Daring dan Pemasaran SMK Negeri 1 Karanaganyar Tahun Pelajaran 2017/20. Jurnal Pendidikan Bisnis Dan Ekonomi, 4, 3.

Dewi, D. T. (2020). Penerapan Problem Based Learning untuk Meningkatkan Kemampuan Berpikir Kritis Siswa. Jurnal Pendidikan Ekonomi Undiksha, 12(1), 2.

Diani, N. L. (2016). Penerapan Model Pembelajaran Kooperatif Tife Numbered Heads Together Berbantuan 
Mdia Gambar Dalam Pembelajaran Ekonomi Siswa Kelas X-1 SMAN 1 Sawan Tahun Ajaran 2015/2016. Jurnal Program Studi Pendidikan Ekonomi (JPPE), 7. https://doi.org/http://dx.doi.org/10.238 87/jjpe.v7i2.7672

Fakhriyah, F. (2014). Penerapan Problem Based Learning Dalam Upaya Mengembangkan Kemampuan Berpikir Kritis Mahasiswa. Jurnal Pendidikan IPA Indonesia, 3(1), 96.

Firman, \& Rahman, S. rahayu. (2020). Pembelajaran Online di Tengah Pandemi Covid-19. Indonesian Journal of Educational Science, 02(02), 81. https://doi.org/https://doi.org/10.3160 5/ijes.v2i2.659

Fitriyani, M. D., \& Kamsi, N. (2020). Penggunaan Aplikasi Zoom Cloud Meeting Pada Proses Pembelajaran Online Sebagai Solusi Di Masa Pandemi Covid 19. 3.

Gikas, J., \& Grant, M. M. (2013). Mobile computing devices in higher education: Student perspectives on learning with cellphones, smartphones \& social media. The Internet and Higher Education, 19, 18-26. https://doi.org/10.1016/j.iheduc.2013. 06.002

Haqien, D., \& Rahman, A. A. (2020). Pemanfaatan Zoom Meeting Untuk Proses Pembelajaran Pada Masa Pandemi Covid-19. 5(1).

Hidayati, N. (2016). Hasil Belajar dan Keterampilan Berpikir Kritis Siswa Madrasah Tsanawiyah dalam Pembelajaran IPA Melalui Kerja Ilmiah (Vol. 13).

J, W, S. (2011). Educational Psychology. New York: McGrawHill.

Kay, K. (2008). Preparing Every Child for the 21 st Century. Partnership for 21st Century Skills APEC.
Kurniawansyah, A. S., \& Siswanto. (2020). Kolaborasi Whatsapp Grup , Zoom Cloud Meeting, Dan Google Drive Sebagai Formula Dalam Pelaksanaan Kegiatan Perkuliahan Online Di Masa Pandemi Covid-19. Jurnal Media Infotama, 16(2), 61-62. https://doi.org/https://doi.org/10.3767 6/jmi.v16i2.1155

Kusuma, J. W., \& Hamidah. (2020). Perbandingan Hasil Belajar Matematika Dengan Penggunaan Platform Whatsapp Grup Dan Webinar Zoom Dalam Pembelajaran Jarak Jauh Pada Masa Pandemik Covid 19. Jurnal Ilmiah Pendidikan Matematika, 5, 101. https://doi.org/https://doi.org/10.2687 7/jipmat.v5i1.5942

Manalu, R. W., \& Siregar, Y. E. (2019). Efektivitas Model Pembelajaran Scramble Terhadap Kemampuan Berpikir Kritis Matematiis Siwa Di SMP Negeri 2 Pandan. Mathematic Education Journal, 2(2), 94.

Marbun, P. (2020). Disain Pembelajaran Onlin Pada Era Dan Pasca Covid-19. CSRID Journal, 12, 133. https://doi.org/ttps://www.doi.org/10.2 2303/csrid.12.2.2020

Masini, N. M., Haris, I. A., \& Indrayani, L. (2019). Studi Komparatif Aktivitas Dan Hasil Belajar Menggunakan Model Pembelajaran Koopratif Tipe Make A Match Pada Mata Pelajaran IPS Di SMP Negeri 1 Sukasada. Jurnal Pendidikan Ekonomi Undiksha, 11(1), 130.

https://doi.org/http://dx.doi.org/10.238 87/jjpe.v11i1.20095

Muslim, I., Halim, A., \& Safitri, R. (2015). Penerapan Model Pembelajaran PBL Untuk Meningkatkan Pengausaan Konsep Dan Keterampilan Berpikir Kritis Siswa Pada Konsep Di SMA Negeri Unggul Harapan Persada. Jurnal Pendidikan Sains Indonesia, 3(2), 38.

Nainggolan yanti, D. (2020). Penerapan 
Model Problem Based Learning (PBL)

Untuk Meningkatkan Kemampuan

Berpikir Kritis Siswa Berbantuan

Aplikasi Math Moblie Learning. Jurnal Pendidikan Matematika, 3(1), 93.

Noordyana, M. A. (2016). Meningkatkan Kemampuan Berpikir Kritis Matematis Siswa melalui Pendekatan Metacognitive Instruction. Jurnal Pendidikan Matematika, 5, 121.

Nuryanti, L., Zubaidah, S., \& Diantoro, M. (2018). Analisis Kemampuan Berpikir Kritis Siswa SMP. Jurnal Pendidikan, 3, 155. https://doi.org/http://dx.doi.org/10.179 77/jptpp.v3i2.10490

Odabas, H. F. (2009). Computers \& Education Effects of an online problem based learning course on content knowledge acquisition and critical thinking skills. Computer \& Education, 53, 132-141. https://doi.org/10.1016/j.compedu.200 9.01.008

Rachmawati, N. Y., \& Rosy, B. (2021). Pengaruh Model Pembelajaran Problem Based Learning ( PBL ) terhadap Kemampuan Berpikir Kritis dan Pemecahan Masalah pada Mata Pelajaran Administrasi Umum Kelas X OTKP di SMK Negeri 10 Surabaya. Jurnal Pendidikan Administrasi Perkantoran, 9(2016), 249.

Rezkillah, I. I., \& Hayanto. (2020). Pengaruh Model Pembelajaran Problem Based Learning Terintegrasi High Order Thingking Skill Terhadap Kemampuan Berpikir Kritis Dan Sikap Percaya Diri. Ndonesian Journal of Science Education, 8, 259. https://doi.org/10.24815/jpsi.v8i2.173 22

Sadikin, A., \& Hamidah, A. (2020). Pembelajaran Daring di Tengah Wabah Covid-19. Jurnal Ilmiah Pendidikan Biologi, 6(1), 216. https://doi.org/https://doi.org/10.2243 7/bio.v6i2.9759

Saepuloh, D., \& Rodiah, S. (2020). Penerapan Pembelajaran Kooperatif Melalui Model Group Investigation Untuk Meningkatkan Literasi Ekonomi Siswa. Jurnal Pendidikan Ekonomi, $\quad 13(1), \quad 32$. https://doi.org/https://dx.doi.org/10.17 977/UM014v13i12020p030

Saepuloh, D., \& Suryani, S. (2020). Improving Student's Creative Thinking And Self-Efficacy Through Project-Based Learning Models. Jurnal Program Studi Pendidikan Ekonomi, $9, \quad 44$. https://doi.org/10.22202/economica.2 020.v9.i1.4250

Santoso, E. (2016). Pengaruh Penggunaan Model Pembelajaran Quantum Terhadap Kemampuan Berpikir Kritis Siswa Matematika Peserta Didik. Jurnal Cakrawala Pendas, 2(1), 59.

Satrio, Y. D., Handayani, S., Abbas, M. H. I., \& Kustiandi, J. (2020). Studi Komparasi Metode Pembelajaran dalam Meningkatkan Literasi Keuangan di Masa Pandemi Covid-19. Jurnal Pendidikan Ekonomi Undiksha, 12(1), 30. https://doi.org/http://dx.doi.org/10.238 87/jjpe.v12i1.25314

Setyorini, U., Sukiswo, \& Subali, B. (2011). Pnerapan Model Problem Based Learning Untuk Meningkatkan Keammpuan Berpikir Kritis Siswa SMP. Jurnal Pendidikan Fisika Indonesia, 7, 52-56.

Simanjuntak, M. F., \& Sudibjo, N. (2019). Menigkatkan Ketrampilan Berpikir Kritis Dan Kemampuan Memecahkan Masalah Siswa Melalui Pembelajaran Berbasis Masalah. Journal of Holistic Mathematics Education, 2(2), 109. https://doi.org/DOI: https://dx.doi.org/10.19166/johme.v2i 2.1331

Sulisworo, D., Kusumaningtyas, D. A., \& 
Handayani, T. (2019). E-Learning Impacts on Critical Thinking Skills in Science Learning. International Journal of Recent Technology and Engineering (IJRTE), (4), 34. https://doi.org/10.35940/ijrte.D6795.1 18419

Summaries, C. E. (2018). PISA 2018 Results. I, 18.

Surur, M., \& Oktavia, S. T. (2019). Pengaruh Model Pembelajaran Discovery LLearning Terhadap Pemahaman Konsep Matematika. Jurnal Pendidikan Edutama), 6(1), $11-18$.

https://doi.org/10.30734/jpe.v6i1.341

Susanto, A. (2013). Teori Belajar \& Pembelajaran di Sekolah Dasar. Jakarta: Kencana.

Tosuncuoglu, I. (2018). Place of Critical Thinking In EFL. Nternational Journal of Higher Education, 7(September), 26.

https://doi.org/10.5430/ijhe.v7n4p26

Widayanti, Y. (2020). Meningkatkan Hasil Belajar Peserta Didik dengan Modul Pembelajaran Berbasis Problem Based Learning ( PBL ). Jurnal Pendidikan Ekonomi Undiksha, 12(1), 167. https://doi.org/http://dx.doi.org/10.238 87/jjpe.v12i1.25648

Yulianto, E., Cahyani, P. D., \& Silvianita, S.
(2020). Perbandingan Kehadiran Sosial dalam Pembelajaran Daring Menggunakan Whatsapp group dan Webinar Zoom Berdasarkan Sudut Pandang Pembelajar Pada Masa Pandemic COVID-19. Jurnal Riset Teknologi Dan Inovasi Pendidikan (JARTIKA), 3(2), 332. https://doi.org/https://doi.org/10.3676 5/jartika.v3i2.277

Yuliati, L. (2013). Efektivitas Bahan Ajar IPA Terpadu Terhadap Kemampuan Berpikir Tingkat Tinggi Siswa SMP. Jurnal Pendidikan Fisika Indonesia, 9, 57.

https://doi.org/https://doi.org/10.1529 4/jpfi.v9i1.2580

Zubaidah, S. (2018). Mengenal 4C: Learning and Innovation Skilss Untuk Menghadapi Era Revolusi Industri 4.0. (October 2018), 2. 
74 JURNAL PENDIDIKAN EDUTAMA, Vol.8, No.2 Juli 2021 